\title{
Giant Benign Mammary Phyllodes Tumor: Report of a Case and Review of the Literature
}

\author{
Ricardo Fernández-Ferreira ${ }^{a} \quad$ Andrés Arroyave-Ramírez ${ }^{a}$ \\ Daniel Motola-Kuba ${ }^{a}$ Gabriela Alvarado-Luna ${ }^{a}$ \\ lleana Mackinney-Noveloa Román Segura-Rivera ${ }^{b}$ \\ aDepartment of Oncology Medicine, Comprehensive Oncology Center "Diana Laura Riojas \\ de Colosio," Medica Sur Clinic and Foundation, Mexico, Mexico; 'bervice of Anatomical \\ Pathology, Medica Sur Clinic and Foundation, Mexico, Mexico
}

\author{
Keywords \\ Giant benign mammary tumor - Phyllodes tumor - Complete surgical excision . \\ Fibroepithelial neoplasm
}

\begin{abstract}
Phyllodes tumor of the breast is an infrequently encountered fibroepithelial neoplasm, which accounts for $0.3-1 \%$ of all tumors. Few case reports have described the occurrence of giant phyllodes tumor. To our knowledge, about $20 \%$ of phyllodes tumors would be considered giant benign. Complete surgical excision is the standard of care for giant benign phyllodes tumors; axillary lymph node metastasis is rare, and dissection should be limited to patients with pathologic evidence of tumor in the lymph nodes. We report the case of a 40-year-old Mexican woman with giant mammary tumor who underwent a right total mastectomy. The pathology results showed a benign phyllodes tumor 4,857 g in weight and $40.2 \times 36.3 \times 15 \mathrm{~cm}$ in size. We do not suggest adjuvant radiation therapy for patients with benign phyllodes tumors that are widely excised. A review of the pertinent literature was performed.
\end{abstract}

\section{Introduction}

Phyllodes tumor of the breast is a rare fibroepithelial neoplasm that accounts for less than $1 \%(0.3-0.5 \%)$ of all female breast neoplasms. The actual incidence of malignant phyllodes tumor is unknown [1-4]. 

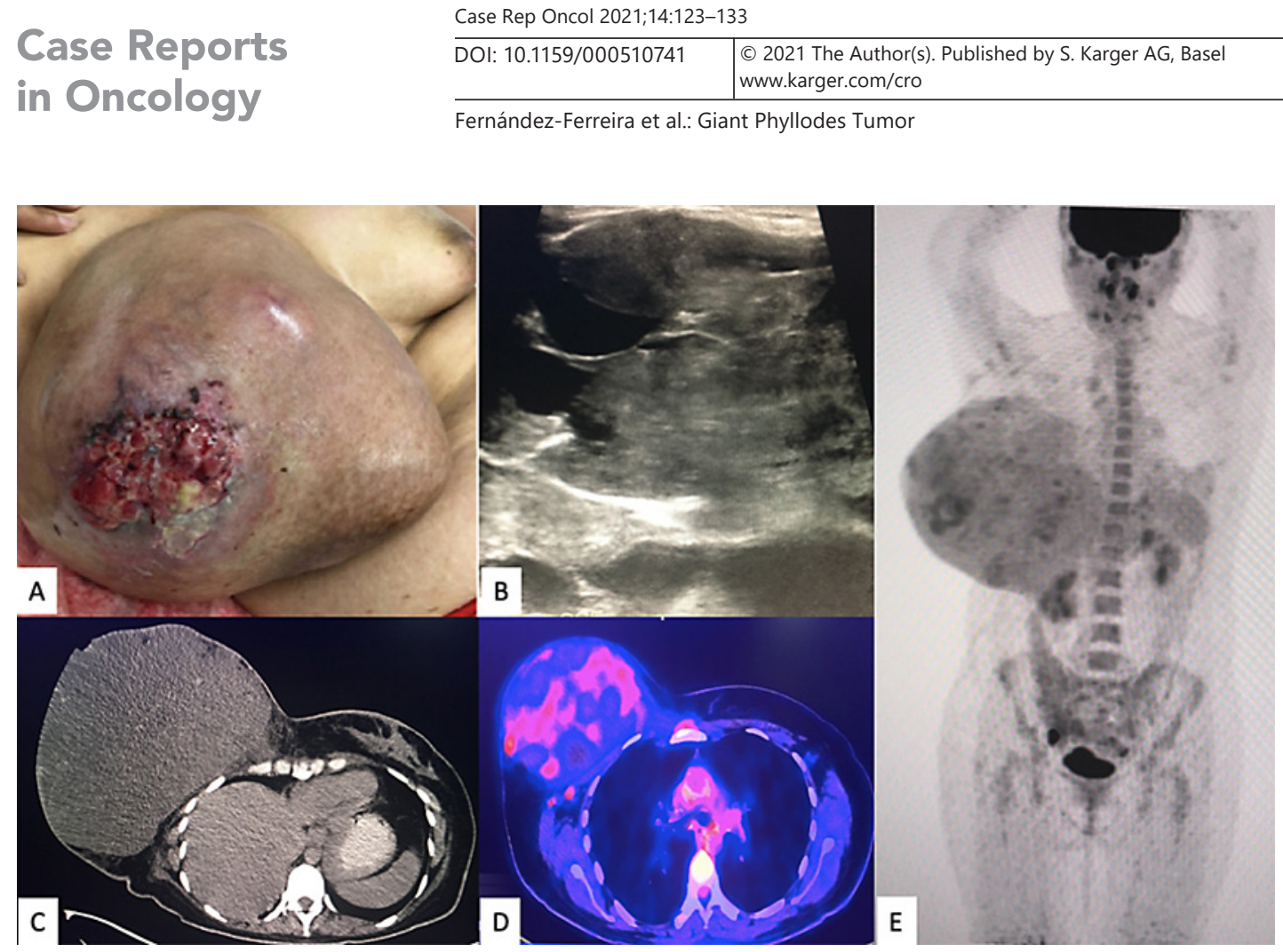

Fig. 1. A A 40-year-old woman presenting with a giant lesion $40.2 \times 36.3 \times 15 \mathrm{~cm}$ in size in her right breast. B Sonography of the breast showed a huge mass with multiple areas of cystic degeneration alternating with solid tissue, poorly defined margins, irregular vascularity, and thick hyperechogenic septa. C-E ${ }^{18}$ F-FDG PET/ CT showed a right breast mass that measured $24.6 \times 17.3 \mathrm{~cm}$ in the axial plane and $22.5 \mathrm{~cm}$ in the cephalocaudal plane, with loss of an interface between it and the pectoralis major muscle, with some hyperdense linear and nodular areas inside, as well as two 9-mm ipsilateral axillary lymphadenopathies.

The term "phyllodes," which means leaf-like, describes the typical papillary projections that are seen on pathologic examination. They were originally called "cystosarcoma phyllodes" by Johannes Müller in 1838 [5]. The terminology has since evolved, with over 60 synonyms having been applied to this entity before the term "phyllodes tumors" was adopted by the World Health Organization [6].

Histologically, phyllodes tumors are classified as benign (60-75\%), borderline (15-20\%), or malignant (10-20\%), based upon the assessment of five features: the degree of stromal cellular atypia; the mitotic activity per 10 high-power fields (HPFs); infiltrative or circumscribed tumor margins; the presence or absence of stromal overgrowth (i.e., the presence of pure stroma devoid of epithelium); and the nature of the tumor borders $[3,4,7]$.

Tumor size is variable, ranging from 1 to $41 \mathrm{~cm}$ (average 4-7 cm). Giant phyllodes tumors are those larger than $10 \mathrm{~cm}$ in diameter, and they account for about $20 \%$ of all phyllodes tumors $[3,8,9]$. Phyllodes tumors should be completely excised; axillary lymph node dissection is not necessary. Adjuvant radiation therapy (RT) may benefit borderline or malignant, but not benign, tumors. Chemotherapy is reserved for highly selected patients with large, high-risk, or recurrent malignant phyllodes tumors [10-12].

Here, we report a case of giant benign phyllodes tumor seen at our hospital. After standard mastectomy with adequate free margins, we treated the skin defect by use of an advanced flap. The patient recovered well.

\section{Karger' ${ }^{\prime \prime}$}




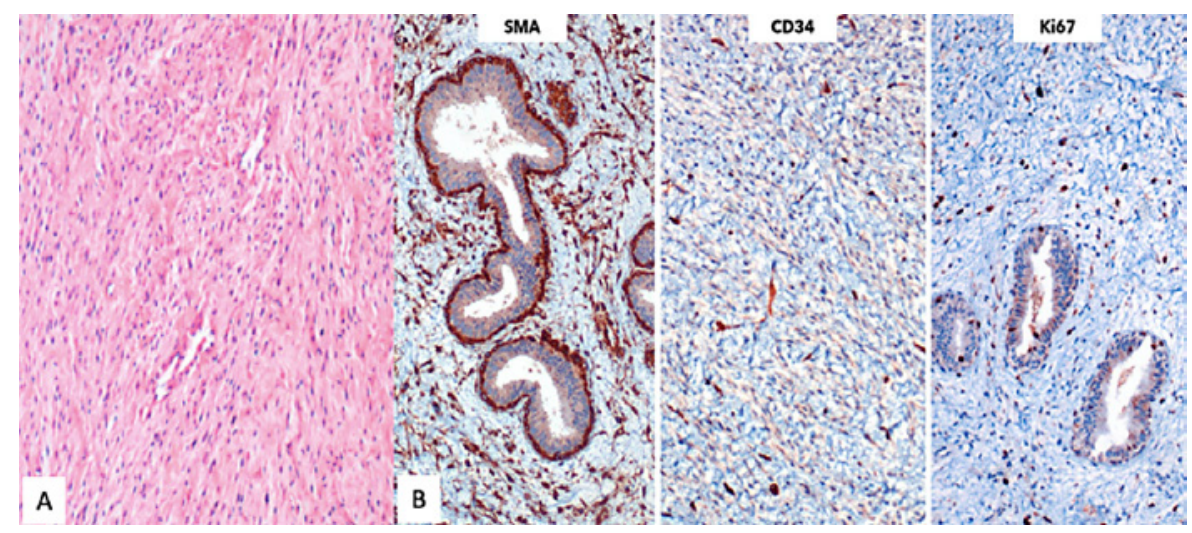

Fig. 2. A Initial core biopsy. The microscopic findings show a biphasic neoplasm. The spindle cell component had hypercellular zones alternating with collagenized stroma and other fields with a myxoid matrix. The ductal epithelium did not show significant atypia, except for some foci with usual ductal hyperplasia. B Immunohistochemically, the fusiform component was positive for SMA and CD34, while the Ki-67 proliferation index was low. CKC was negative in the spindle cells.

\section{Case Report}

A 40-year-old Mexican woman presented to our hospital with a giant tumor in her right breast. The patient had noticed the mass 3 years earlier; 1 year later, blisters had appeared on the nipple. In the last year, the mass had presented with erythema, a venous network, a foul smell, and skin ulceration with bleeding, and it had also increased considerably in size. Due to the rapid growth, the patient consulted us for help. The family and personal history did not provide any information relevant to the case. Physical examination revealed an enlarged right breast, approximately $25 \times 22 \mathrm{~cm}$, with irregular margins, erythematous and hyperemic skin, ulceration of the nipple with hemorrhagic discharge, pain on palpation, and the axillary region without nodes (Fig. 1A). Laboratory tests only showed leukocytosis $(12,700 / \mu \mathrm{L})$ with neutrophilia $(9,700 / \mu \mathrm{L})$, without any other significant finding. Sonography of the breast showed a huge mass with multiple areas of cystic degeneration alternating with solid tissue, poorly defined margins, irregular vascularity, and thick hyperechogenic septa. An ultrasound-guided biopsy was performed, and the histopathology results showed a fibroepithelial neoplasm with hyalinized, myxoid, and hypercellular stromal areas, compatible with fibroadenoma, with a Ki-67 proliferation index of 2\% (Fig. 1B, 2).

Subsequently, ${ }^{18} \mathrm{~F}$-FDG PET/CT showed a right breast mass that measured $24.6 \times 17.3 \mathrm{~cm}$ in the axial plane and $22.5 \mathrm{~cm}$ in the cephalocaudal plane, with loss of an interface between it and the pectoralis major muscle, with some hyperdense linear and nodular areas inside, as well as two 9-mm ipsilateral axillary lymphadenopathies (Fig. 1C-E). The patient underwent a right total mastectomy. The postoperative period was uneventful; the patient recovered well and she went home after 3 days of hospitalization. The pathology results showed a solid, multilobed, and heterogeneous tumor 4,857 g in weight and $40.2 \times 36.3 \times 15 \mathrm{~cm}$ in size. Moreover there was a skin ulceration of $8 \mathrm{~cm}$ in the nipple (Fig. 3A). Microscopically, the sections showed a benign mixed fibroepithelial neoplasm with areas of fibroadenoma and benign phyllodes tumor, as well as tumor-free surgical margins (Fig. 3, 4). During follow-up, there has been no evidence of local relapse or distant metastases to date. 

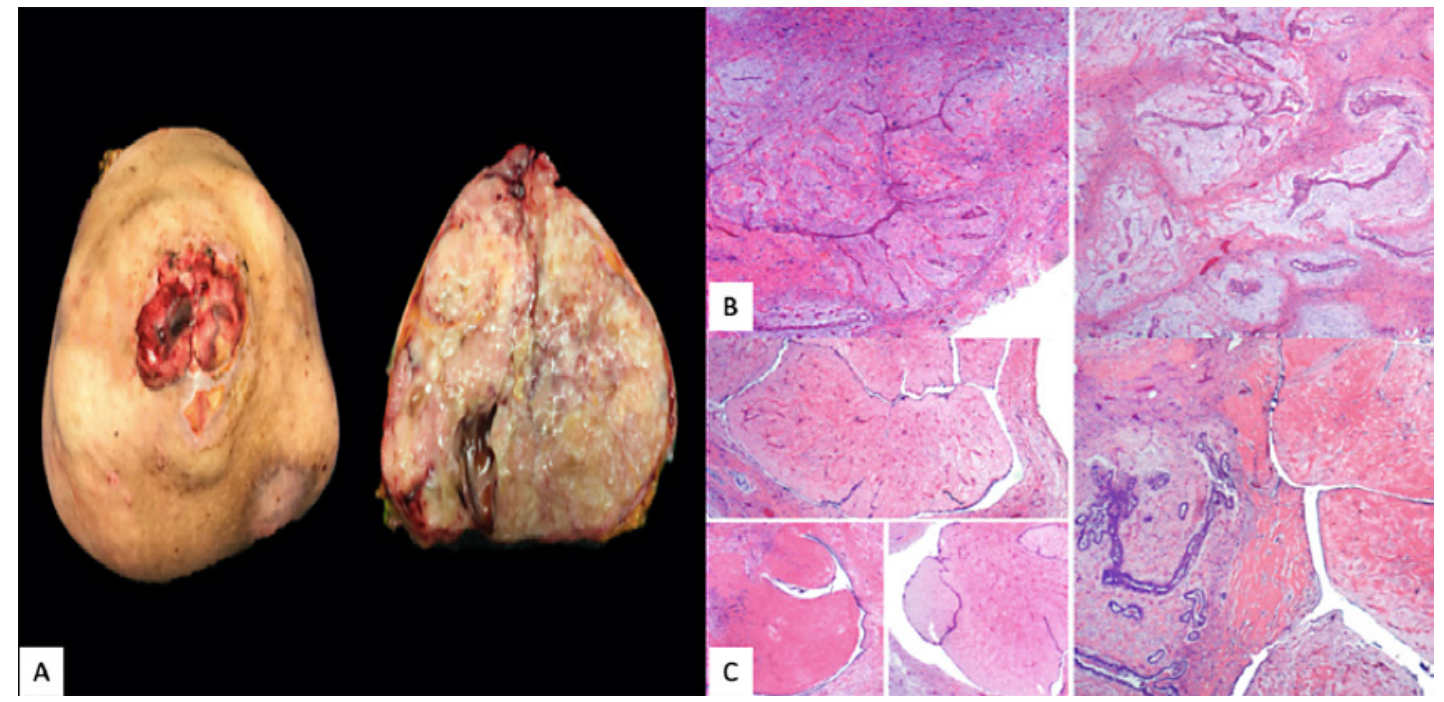

Fig. 3. A Surgical specimen. Grossly, the nipple area was extensively ulcerated. The tumor measured $40.2 \mathrm{~cm}$ in the greatest diameter. The cut surface presented whitish and yellowish areas. Its heterogeneous consistency was distinguished by prominent firm areas, with other friable and mucoid-like zones. Deeper cystic degeneration was identified. It should be noted that the tumor was entirely lobed, with pushing edges. B Microscopically, the tumor had mixed features. In some areas, the classic pattern of fibroadenoma was evident: ductal epithelial-lined clefts with variable hyperplasia immersed in a paucicellular stroma with a myxoid and collagenized matrix with a lobulated architecture. C These sites alternated with larger leaf-like projections, remarkably hyalinized and with a bland ductal epithelium, consistent with benign phyllodes tumor.

\section{Discussion}

Phyllodes tumors are an uncommon type of fibroepithelial neoplasm of the breast and present on a morphologic continuum from benign to malignant. In a study from Los Angeles county over a 17-year period, the average annual age-adjusted incidence rate of malignant cystosarcoma phyllodes was 2.1 per 1 million women. Latina whites have a higher risk of this cancer than other racial-ethnic groups (non-Latina whites, Asians, and African Americans) $[7,13]$.

Phyllodes tumors can vary in size but are frequently large, with a median size of $4-5 \mathrm{~cm}$. Few case reports have described the occurrence of giant phyllodes tumors, which are phyllodes tumors of a size greater than $10 \mathrm{~cm}$. Sizes described range from 15 to $50 \mathrm{~cm}$. The tumor described here is one of the largest reported in the literature. $73 \%$ of benign phyllodes tumors are smaller than $5 \mathrm{~cm}$, and those that are larger than $7 \mathrm{~cm}$ are associated with malignancy. About $20 \%$ of phyllodes tumors would be considered giant benign. Phyllodes tumor occurs mainly in women, although there are reports of some cases in men. They can occur in women of a median age at presentation of 42-45 years (range 10-82), about 15-20 years later than fibroadenomas. In men, phyllodes tumors usually occur in association with gynecomastia. Higher-grade tumors are more common in older patients [3, 8, 9, 14-38].

Genetic risk factors for phyllodes tumors are largely unknown, but the literature describes phyllodes tumors in Li-Fraumeni syndrome patients and a mother-daughter pair [39, 40]. Stromal induction of phyllodes tumors can occur due to growth factors produced by the breast epithelium and stromal expression of endothelin-1, insulin-like growth factors (IGF-I and II), and epithelial overexpression of Wnt5a in benign/borderline phyllodes tumors. 


\section{Case Reports in Oncology}

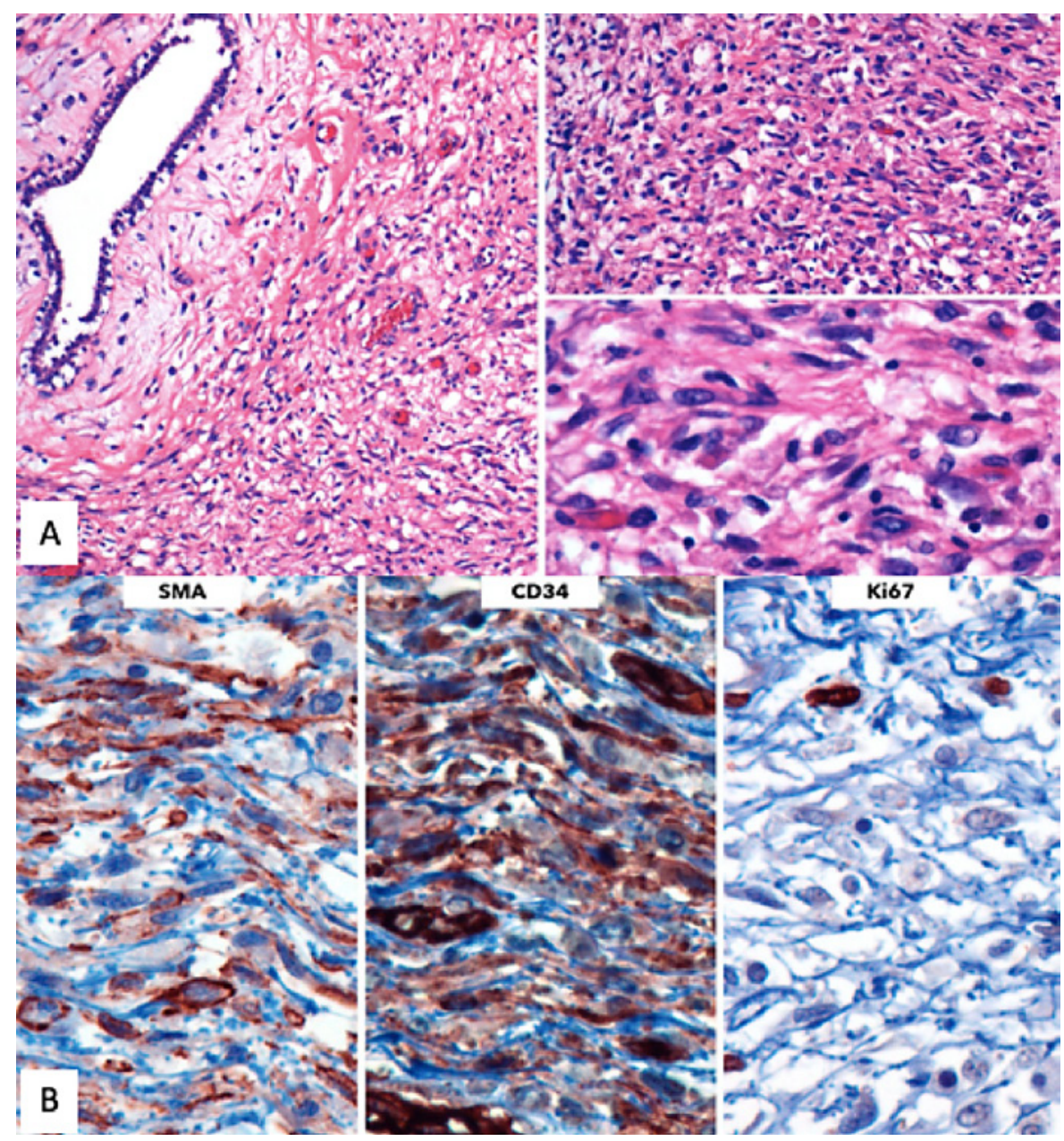

Fig. 4. A In some areas, condensation of the spindle cell component around epithelial structures was notable. Mitoses were infrequent, quantified up to 4 in 10 high-power fields. Necrosis was absent. Neither stromal overgrowth nor heterologous components were found. B The immunophenotype of the lesion was consistent with that evidenced in the initial core biopsy, with positivity for SMA and CD34 and a low Ki-67 proliferation index. Due to its lack of malignant features, a diagnosis of benign mixed fibroepithelial neoplasm was rendered.

Trauma, pregnancy, increased estrogen activity, and lactation occasionally have been implicated as factors stimulating tumor growth [41-43].

Phyllodes tumors may grow slowly or rapidly or exhibit a biphasic growth pattern. As they grow larger, phyllodes tumors can form a visible mass that distorts the contour of the breast or even cause pressure necrosis of the overlying skin. Unlike breast carcinomas, phyllodes tumors start outside of the lobules and ducts, in the breast's connective tissue, called the stroma, which includes the ligaments and fatty tissue that surround the lobules, ducts, and lymph and blood vessels in the breast. Phyllodes tumors can also contain stromal cells [44, 45]. They most likely develop de novo, although there have been reports of progression of fibroadenoma to phyllodes tumor [45, 46].

Recent studies have focused on defining a molecular classification of phyllodes tumor. Comparative genomic hybridization studies showed recurrent chromosome imbalances, including $+1 q,-6 q,-13 q,-9 p,-10 p$, and $+5 p$. Although to date no chromosomal aberrations 
have been found to be specific to phyllodes tumor, Laé et al. [47] reported that low-grade (benign) and high-grade (borderline/malignant) phyllodes tumors segregate into two genetic groups based on genomic alterations, with high-grade phyllodes tumor consistently showing 1q gain and 13q loss and low-grade phyllodes tumor showing few or no alterations $[47,48]$. Preliminary data from array comparative genomic hybridization demonstrate interstitial deletion 9p21 involving the CDKN2A locus and 9p deletion in malignant and some borderline phyllodes tumors [49]. Recurrent mediator complex subunit 12 (MED12) somatic mutations, frequently (50-70\%) in uterine leiomyomas, have recently been identified in fibroadenomas (59-67\%) and phyllodes tumors (45-67\%). In addition, MED12 is frequently mutated in all phyllodes tumors. These findings suggest that both entities may share a genetic etiology, and MDM2 mutation is an early event of fibroadenoma and phyllodes tumor pathogenesis [47, 50].

On examination, most patients have a smooth, multinodular, well-defined, firm mass that is mobile and painless. Shiny, stretched, and attenuated skin may be seen overlying a large tumor. Nipple retraction, ulceration, chest wall fixation, and bilateral diseases are rare (33\%), but have been described for phyllodes tumors. The most frequent location is in the right breast, being multicentric in a third of cases; $35 \%$ are in the upper external quadrant, $15 \%$ in the upper internal quadrant, $10-25 \%$ in the lower external quadrant, and fewer than $10 \%$ in the lower internal quadrant $[3,10,16,44,51,52]$. Although palpable axillary lymphadenopathy can be identified in up to $20 \%$ of patients, most cases are reactive; metastatic involvement of lymph nodes with phyllodes tumor is rare [51-53].

Phyllodes tumors should be suspected when a patient presents with a large $(>3-\mathrm{cm})$, rapidly growing breast mass that is usually palpable. Although imaging features of a phyllodes tumor can be suggestive of fibroadenoma, the large size and history of rapid growth indicate otherwise. Approximately $20 \%$ of phyllodes tumors present as a nonpalpable mass identified on screening mammography. The typical appearance of a phyllodes tumor on mammography is a smooth, polylobulated mass resembling a fibroadenoma; calcifications within the mass are rare, but they can be large [52-54]. On ultrasound, phyllodes tumors present as a hypoechoic, solid, partially indistinct or partially circumscribed mass with frequent posterior enhancement. A cystic component is more typical in malignant phyllodes tumors. Frequently, phyllodes tumors will show increased vascularity on color or power Doppler [55]. Breast MRI may help determine the extent of disease and resectability in selected cases. The characteristics on MRI are seen as well-circumscribed tumors with irregular walls, high signal intensity on T1-weighted images, and low signal intensity on T2-weighted images. Cystic change may be seen as well. A rapid enhancement pattern is seen more commonly with benign rather than with malignant phyllodes tumors, which is the opposite of the pattern seen with adenocarcinomas of the breast [54-57]. ${ }^{18}$ F-FDG PET/CT therefore is useful in imaging recurrent phyllodes tumors, since it can display rare unsuspected sites of metastasis [57].

Breast lesions suspicious for phyllodes tumors should undergo core biopsy, which is typically diagnostic. Compared with core biopsy, fine needle aspiration is less accurate. Grossly, phyllodes tumors may be indistinguishable from fibroadenomas. They are round-to-oval multinodular masses with a grayish-white appearance that resemble the head of a cauliflower. Phyllodes tumors grow radially, creating a pseudocapsule through which tongues of stroma may protrude and grow into adjacent breast tissue. Necrosis and hemorrhage can occur in larger tumors. Microscopically, the characteristic leaf-like architecture consists of elongated cleft-like spaces that contain papillary projections of epithelial-lined stroma with varying degrees of hyperplasia and atypia. The stromal elements are a key component in differentiating phyllodes tumors from fibroadenomas and in differentiating a benign tumor from a malignant one $[16,47,54,58]$. Phyllodes tumor is classified as benign, borderline, or malignant according to the WHO classification of 2012 [59] (Table 1).

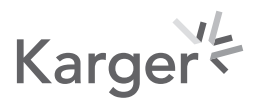


Fernández-Ferreira et al.: Giant Phyllodes Tumor

Table 1. Three-tiered grading system for phyllodes tumors based on the 2012 World Health Organization classification

\begin{tabular}{|c|c|c|c|c|c|c|}
\hline \multirow[t]{2}{*}{ Type } & \multirow[t]{2}{*}{ Characteristics } & \multicolumn{5}{|c|}{ Histologic features } \\
\hline & & $\begin{array}{l}\text { stromal } \\
\text { hypercellularity }\end{array}$ & $\begin{array}{l}\text { stromal } \\
\text { mitotic } \\
\text { activity }\end{array}$ & $\begin{array}{l}\text { stromal } \\
\text { cell atypia/ } \\
\text { overgrowth }\end{array}$ & $\begin{array}{l}\text { tumor } \\
\text { borders }\end{array}$ & $\begin{array}{l}\text { malignant } \\
\text { heterologous } \\
\text { differenti- } \\
\text { ation }\end{array}$ \\
\hline $\begin{array}{l}\text { Benign } \\
\text { phyllodes } \\
\text { tumors }\end{array}$ & $\begin{array}{l}\text { This variety comprises } 60-75 \% \text { of all } \\
\text { phyllodes tumors } \\
\text { The stroma is usually more cellular } \\
\text { than in fibroadenomas }\end{array}$ & $\begin{array}{l}\text { Mild, } \\
\text { non-uniform or } \\
\text { diffuse }\end{array}$ & $\begin{array}{l}0-4 / 10 \\
\mathrm{HPF}\end{array}$ & $\begin{array}{l}\text { Mild or } \\
\text { none/ } \\
\text { absent }\end{array}$ & $\begin{array}{l}\text { Circumscribed, } \\
\text { pushing }\end{array}$ & Absent \\
\hline $\begin{array}{l}\text { Borderline } \\
\text { phyllodes } \\
\text { tumors }\end{array}$ & $\begin{array}{l}\text { This variety comprises } 15-20 \% \text { of all } \\
\text { phyllodes tumors } \\
\text { These tumors are diagnosed if the } \\
\text { mass does not possess all the adverse } \\
\text { histological characteristics found in } \\
\text { malignant phyllodes tumors }\end{array}$ & $\begin{array}{l}\text { Moderate, } \\
\text { non-uniform or } \\
\text { diffuse }\end{array}$ & $\begin{array}{l}5-9 / 10 \\
\mathrm{HPF}\end{array}$ & $\begin{array}{l}\text { Mild or } \\
\text { moderate/ } \\
\text { may be } \\
\text { focal }\end{array}$ & $\begin{array}{l}\text { Circumscribed } \\
\text { or focally } \\
\text { infiltrative }\end{array}$ & Absent \\
\hline $\begin{array}{l}\text { Malignant } \\
\text { phyllodes } \\
\text { tumors }\end{array}$ & $\begin{array}{l}\text { This variety comprises } 10-20 \% \text { of all } \\
\text { phyllodes tumors }\end{array}$ & $\begin{array}{l}\text { Marked, usually } \\
\text { diffuse }\end{array}$ & $\begin{array}{l}\geq 10 / 10 \\
\text { HPF }\end{array}$ & $\begin{array}{l}\text { Marked } \\
\text { usually } \\
\text { present, may } \\
\text { be diffuse }\end{array}$ & $\begin{array}{l}\text { Infiltrative } \\
\text { y }\end{array}$ & Present \\
\hline
\end{tabular}

Multiple immunohistochemistry markers have undergone study in an attempt to improve the classification of phyllodes tumors and to predict their outcomes. Studies have demonstrated that p53, Ki67, CD117, EGFR, p16, and VEGF (being lowest in benign phyllodes tumors and highest in malignant phyllodes tumors) are associated with the histologic grade of phyllodes tumors, but none has been proven to be clinically useful [60-63]. Differential diagnoses are fibroadenoma, sarcoma, periductal stromal tumor, and metaplastic carcinoma [64-67].

Regarding treatment, complete surgical excision is the standard of care for phyllodes tumors, and with greater than 1-cm margins is often curative and reduces the risk of local recurrence [11]. Mastectomy is generally not indicated for benign phyllodes tumor, unless negative margins cannot be achieved and/or if a tumor is so large that breast-conserving surgery would result in suboptimal cosmetic outcomes. A 2019 meta-analysis of 54 observational studies also found that a positive margin only correlated with a higher local recurrence risk of malignant, but not of benign and borderline, phyllodes tumors [68]. Surgical margins of greater than or equal to $1 \mathrm{~cm}$ have been associated with a lower local recurrence rate in borderline and malignant phyllodes $[3,69]$.

When adequate surgical margins cannot be achieved because of tumor location, adjuvant RT should be administered, even after mastectomy. However, if adequate surgical margins can be achieved, there is less agreement about the need for adjuvant RT. We base our decision about adjuvant RT on tumor grade; thus, we do not suggest adjuvant RT for patients with benign phyllodes tumors that are widely excised, whereas we suggest adjuvant RT for patients with borderline or malignant phyllodes tumors following surgical excision [69-73].

Axillary lymph node involvement by phyllodes tumors is rarely reported, even when tumors are malignant. In the SEER database study, only 8 of 498 women with known lymph node status had involved nodes [72]. Thus, axillary surgery is rarely indicated in patients diagnosed with phyllodes tumors.

Due to scarce data, the role of systemic chemotherapy in phyllodes tumors is limited. Patients with benign or borderline phyllodes tumors are usually cured with surgery and should not be offered chemotherapy unless they develop unresectable metastases. Based on 
experience and limited data, we recommend adjuvant chemotherapy only to a small minority of patients with high-risk $(>10-\mathrm{cm})$ or recurrent malignant phyllodes tumors who have excellent functional status and minimal comorbidities, and only after a thorough discussion about the risks, benefits, and controversial nature of such treatment. When systemic chemotherapy is indicated, malignant phyllodes tumors should be treated according to protocols designed for soft tissue sarcoma rather than breast cancers [74]. Hormone therapy is not effective against phyllodes tumors $[51,75]$.

When phyllodes tumors recur, they typically recur locally within 2 years of the initial excision $[3,51]$. Some series have found that the time to local recurrence was shorter for malignant than for benign or borderline tumors. Although recurrences typically have the same grade as the original tumors, there have been several case reports of benign tumors transforming into malignant ones upon recurrence $[9,72,76,77]$. Despite the best surgical efforts, phyllodes tumors are known to recur locally at rates that vary with tumor grade. As an example, a 2019 meta-analysis of 54 retrospective studies reported an overall local recurrence rate of $12 \%$ (95\% CI 10-14), as well as pooled local recurrence rates of 8,13 , and $18 \%$ for benign, borderline, and malignant tumors, respectively [68]. Local recurrences generally develop within 2-3 years.

Most clinically malignant/metastatic phyllodes tumors have had overgrowth of one or several sarcomatous elements (4-7\%). These elements include liposarcoma (7\%), rhabdosarcoma, chondrosarcoma, osteosarcoma (1.3\%), and undifferentiated/unclassified sarcoma $[78,79]$. Distant metastases are almost exclusively a feature of malignant phyllodes tumors. The lungs (66\%), the bones (28\%), and the brain (9\%) are the most common sites of spread [54]. Rarely, metastases can involve the liver and heart $(<5 \%)$. Tumors that metastasize are typically large $(\geq 5 \mathrm{~cm}$ ) or have malignant histologic features (benign: $0.13-3.2 \%$; borderline: 1.6-11\%; malignant: 16.7-28.6\%) [79].

The impact of histology on survival was explored in the SArcoma and PHYllode Retrospective (SAPHYR) study. The overall 3-year survival rate for combined benign and borderline tumors was $100 \%$ [79]. The overall 3-year survival rate for malignant phyllodes tumors was $54 \%$, similar to that for non-angiosarcoma primary breast sarcomas (60\%). Also, the 5-year overall survival rate for patients with benign/borderline and those with malignant tumors was 91 and $82 \%$, respectively [76].

\section{Conclusions}

Phyllodes tumors are uncommon fibroepithelial breast tumors that are capable of a diverse range of biologic behaviors. Giant phyllodes tumors account for about $20 \%$ of all phyllodes tumors. Given the rarity of the disease, treatment principles are based mainly on retrospective series and case reports. Mastectomy is the standard of care for giant benign phyllodes tumors.

\section{Acknowledgments}

Thanks are due to the Southern Medical Hospital for their support in data collection.

\section{Statement of Ethics}

The patient gave informed written consent to publish her case (including the publication of images).

\section{Karger'}




\section{Conflict of Interest Statement}

The authors have no conflicts of interest to declare.

\section{Funding Sources}

No funding was received.

\section{Author Contributions}

The authors contributed to the conception of the case report, to the analysis and critical revision of the content, and to the final approval of the version to be published. A. ArroyaveRamírez, D. Motola-Kuba, G. Alvarado-Luna, and I. Mackinney-Novelo contributed to critical revision of the content, as well as to the final approval of the version to be published. $\mathrm{R}$. Segura-Rivera carried out the exhaustive review of the histopathological characteristics of phyllodes tumor and analysis of the article. All authors agree to be responsible for all aspects of the work to ensure that questions related to the accuracy or completeness of any part of the work are properly investigated and resolved.

\section{References}

1 Rowell MD, Perry RR, Hsiu JG, Barranco SC. Phyllodes tumors. Am J Surg. 1993;165(3):376-9.

2 Donegan WL. Sarcoma of the breast. Major Probl Clin Surg. 1979;5:504-42.

3 Reinfuss M, Mituś J, Duda K, Stelmach A, Ryś J, Smolak K. The treatment and prognosis of patients with phyllodes tumor of the breast: an analysis of 170 cases. Cancer. 1996;77(5):910-6.

4 Geisler DP, Boyle MJ, Malnar KF, McGee JM, Nolen MC, Fortner SM, et al. Phyllodes tumors of the breast: a review of 32 cases. Am Surg. 2000;66(4):360-6.

5 Calhoun K, Lawton TJ, Kim JM, Lehman CD, Anderson BO. Phyllodes tumors. In: Harris J, Lippman ME, Osborne CK, Morrow M, editors. Diseases of the breast. Philadelphia: Lippincott Williams \& Wilkins; 2010. p. 781-92.

6 Hanby AM, Walker C. Tavassoli FA, Devilee P: Pathology and genetics: tumours of the breast and female genital organs. WHO Classification of Tumours series - volume IV. Lyon, France: IARC Press. Breast Cancer Res. 2004; 6:133.

7 Fajdić J, Gotovac N, Hrgović Z, Kristek J, Horvat V, Kaufmann M. Phyllodes tumors of the breast diagnostic and therapeutic dilemmas. Onkologie. 2007;30(3):113-8.

8 Liang MI, Ramaswamy B, Patterson CC, McKelvey MT, Gordillo G, Nuovo GJ, et al. Giant breast tumors: surgical management of phyllodes tumors, potential for reconstructive surgery and a review of literature. World J Surg Oncol. 2008;6:117.

9 Barrio AV, Clark BD, Goldberg JI, Hoque LW, Bernik SF, Flynn LW, et al. Clinicopathologic features and longterm outcomes of 293 phyllodes tumors of the breast. Ann Surg Oncol. 2007;14(10):2961-70.

10 Limaiem F, Kashyap S. Cancer, phyllodes tumor of the breast (cystosarcoma). Treasure Island (FL): StatPearls Publishing; 2020.

11 Pezner RD, Schultheiss TE, Paz IB. Malignant phyllodes tumor of the breast: local control rates with surgery alone. Int J Radiat Oncol Biol Phys. 2008;71(3):710-3.

12 Bernstein L, Deapen D, Ross RK. The descriptive epidemiology of malignant cystosarcoma phyllodes tumors of the breast. Cancer. 1993;71(10):3020-4.

13 Rosen PP. Fibroepithelial neoplasms. In: Weinberg RW, Donnellan K, Palumbo R, editors. Rosen's breast pathology. 2nd ed. Philadelphia: Lippincott Williams \& Wilkins; 2001. p. 176-200.

14 Ogunbiyi S, Perry A, Jakate K, Simpson J, George R. Phyllodes tumour of the breast and margins: How much is enough. Can J Surg. 2019;62(1):E19-21.

15 Karim RZ, Gerega SK, Yang YH, Spillane A, Carmalt H, Scolyer RA, et al. Phyllodes tumours of the breast: a clinicopathological analysis of 65 cases from a single institution. Breast. 2009;18(3):165-70.

16 Jing P, Wei B, Yang X. Phyllodes tumor of the breast with nipple discharge: a case report. Medicine (Baltimore). 2018 Dec;97(52):e13767.

17 Nielsen VT, Andreasen C. Phyllodes tumour of the male breast. Histopathology. 1987 Jul;11(7):761-2.

18 Birch JM, Alston RD, McNally RJ, Evans DG, Kelsey AM, Harris M, et al. Relative frequency and morphology of cancers in carriers of germline TP53 mutations. Oncogene. 2001;20(34):4621-8. 
19 Kallam AR, Kanumury V, Korumilli RM, Gudeli V, Polavarapu H. Massive benign phyllodes tumour of breast complicating pregnancy. J Clin Diagn Res. 2017;11(5):PD08-9.

20 Yan Z, Gudi M, Lim SH. A large benign phyllodes tumour of the breast: a case report and literature review. Int J Surg Case Rep. 2017;39:192-5.

21 Paryani J, Gupta S, Chaturvedi A, Kumar V, Akhtar N, Aggarwal P, et al. A giant malignant phyllodes tumour of the breast: a rare entity. Indian J Gynecol Oncolog. 2017;15:30.

22 Paryani JA. Huge benign phyllodes tumour of the breast: a rare entity. Indian J Surg Oncol. 2019;10:389-91.

23 Liu M, Yang S, Liu B, Guo L, Bao X, Liu B, et al. Giant malignant phyllodes tumor of the breast: a rare case report and literature review. Oncol Lett. 2016;12(1):121-4.

24 Islam S, Shah J, Harnarayan P, Naraynsingh V. The largest and neglected giant phyllodes tumor of the breast - a case report and literature review. Int J Surg Case Rep. 2016;26:96-100.

25 Krishnamoorthy R, Savasere T, Prabhuswamy VK, Babu R, Shivaswamy S. Giant malignant phyllodes tumour of breast. Case Rep Oncol Med. 2014;2014:956856.

26 Testori A, Meroni S, Errico V, Travaglini R, Voulaz E, Alloisio M. Huge malignant phyllodes breast tumor: a real entity in a new era of early breast cancer. World J Surg Oncol. 2015;13:81.

27 Kumar T, Patel MD, Bhargavan R, Kumar P, Patel MH, Kothari K, et al. Largest phyllodes tumor - case report and brief review article. Indian J Surg Oncol. 2011;2(2):141-4.

28 Sbeih MA, Engdahl R, Landa M, Ojutiku O, Morrison N, Depaz H. A giant phyllodes tumor causing ulceration and severe breast disfigurement: case report and review of giant phyllodes. J Surg Case Rep. 2015;2015(12): rjv162.

29 Schillebeeckx C, Verbeeck G, Daenen G, Servaes D, Bronckaers M. A giant phyllodes tumor of the breast. Rare Tumors. 2016;8(3):6299.

30 Hsu SD, Chou SJ, Hsieh HF, Chen TW, Cheng MF, Yu JC. Giant malignant mammary phyllodes tumor: report of a case and review of the literature. Onkologie. 2007;30(1-2):45-7.

31 Alves de Souza J, Marques EF, Guatelli C, Santiago Girao D, Queroz T, Graziano L, et al. Malignant phyllodes tumor of the breast: case report. Rev Assoc Med Bras (1992). 2011;57(5):495-7.

32 Sarvanandan R, Thangaratnam R, Leong AC. Immediate latissimus dorsi pedicle flap reconstruction following the removal of an eight kilogram giant phyllodes tumour of the breast: a case report. J Med Case Rep. 2011;5: 44.

33 Nabi J, Quamrul Akhter SM, Authoy FN. A case of large phyllodes tumor causing "rupture" of the breast: a unique presentation. Case Rep Oncol Med. 2013;2013:871292.

34 Sbeih MA, Engdahl R, Landa M, Ojutiku O, Morrison N, Depaz H. A giant phyllodes tumor causing ulceration and severe breast disfigurement: case report and review of giant phyllodes. J Surg Case Rep. 2015;2015(12): rjv162.

35 Likhitmaskul T, Asanprakit W, Charoenthammaraksa S, Lohsiriwat V, Supaporn S, Vassanasiri W, et al. Giant benign phyllodes tumor with lactating changes in pregnancy: a case report. Gland Surg. 2015;4(4):339-43.

36 Xia D, Zuo H, Quan Y, Dong H, Xu L. Giant phyllodes tumor of the breast: a case report. Chin Ger J Clin Oncol. 2010;9(11):674-6.

37 Khajotia R, Poovaneswaran S, Pavadai T, Sabaratnam S, Khairan H. Unusually large breast tumour in a middleaged woman. Can Fam Physician. 2014;60(2):142-6.

38 Banno A, Shimada A, Aga K, Harada H, Kaburagi T, Seki H, et al. Total mastectomy and chest reconstruction for a rapidly progressing giant phyllodes tumor with skin necrosis: a case report. Surg Case Rep. 2015;1:82.

39 Foucar CE, Hardy A, Siziopikou KP, Wang L, Parini V, Hansen N, et al. A mother and daughter with phyllodes tumors of the breast. Clin Breast Cancer. 2012 Oct;12(5):373-7.

40 Mishra SP, Tiwary SK, Mishra M, Khanna AK. Phyllodes tumor of breast: a review article. ISRN Surg. 2013; 2013:361469.

41 Sawyer EJ, Hanby AM, Rowan AJ, Gillett CE, Thomas RE, Poulsom R, et al. The Wnt pathway, epithelial-stromal interactions, and malignant progression in phyllodes tumours. J Pathol. 2002;196(4):437-44.

42 Sawyer EJ, Hanby AM, Poulsom R, Jeffery R, Gillett CE, Ellis IO, et al. Beta-catenin abnormalities and associated insulin-like growth factor overexpression are important in phyllodes tumours and fibroadenomas of the breast. J Pathol. 2003;200(5):627-32.

43 Mitus JW, Blecharz P, Jakubowicz J, Reinfuss M, Walasek T, Wysocki W. Phyllodes tumors of the breast. The treatment results for 340 patients from a single cancer centre. Breast. 2019;43:85-90.

44 Limaiem F, Kashyap S. Cancer, phyllodes tumor of the breast (cystosarcoma) [updated 2020 Apr 21]. In: StatPearls [Internet]. Treasure Island (FL): StatPearls Publishing; 2020. Available from: https://www-ncbi-nlmnih-gov.pbidi.unam.mx:2443/books/NBK541138/.

45 Faridi SH, Siddiqui B, Ahmad SS, Aslam M. Progression of fibroadenoma to malignant phyllodes tumour in a 14-year female. J Coll Physicians Surg Pak. 2018;28(1):69-71.

46 Zhang Y, Kleer CG. Phyllodes tumor of the breast: histopathologic features, differential diagnosis, and molecular/genetic updates. Arch Pathol Lab Med. 2016;140(7):665-71.

47 Laé M, Vincent-Salomon A, Savignoni A, Fréneaux P, Sigal-Zafrani B, Aurias A, et al. Phyllodes tumors of the breast segregate in two groups according to genetic criteria. Mod Pathol. 2007;20(4):435-44.

48 Jones AM, Mitter R, Springall R, Graham T, Winter E, Gillett C, et al.; Phyllodes Tumour Consortium. A comprehensive genetic profile of phyllodes tumours of the breast detects important mutations, intra-tumoral genetic heterogeneity and new genetic changes on recurrence. J Pathol. 2008;214(5):533-44. 
49 Ng CC, Tan J, Ong CK, Lim WK, Rajasegaran V, Nasir ND, et al. MED12 is frequently mutated in breast phyllodes tumours: a study of 112 cases. J Clin Pathol. 2015;68(9):685-91.

50 Telli ML, Horst KC, Guardino AE, Dirbas FM, Carlson RW. Phyllodes tumors of the breast: natural history, diagnosis, and treatment. J Natl Compr Canc Netw. 2007;5(3):324-30.

51 Macdonald OK, Lee CM, Tward JD, Chappel CD, Gaffney DK. Malignant phyllodes tumor of the female breast: association of primary therapy with cause-specific survival from the Surveillance, Epidemiology, and End Results (SEER) program. Cancer. 2006;107(9):2127-33.

52 Gullett NP, Rizzo M, Johnstone PA. National surgical patterns of care for primary surgery and axillary staging of phyllodes tumors. Breast J. 2009;15(1):41-4.

53 Tan H, Zhang S, Liu H, Peng W, Li R, Gu Y, et al. Imaging findings in phyllodes tumors of the breast. Eur J Radiol. 2012 Jan;81(1):e62-9.

54 Liberman L, Bonaccio E, Hamele-Bena D, Abramson AF, Cohen MA, Dershaw DD. Benign and malignant phyllodes tumors: mammographic and sonographic findings. Radiology. 1996 Jan;198(1):121-4.

55 Yabuuchi H, Soeda H, Matsuo Y, Okafuji T, Eguchi T, Sakai S, et al. Phyllodes tumor of the breast: correlation between MR findings and histologic grade. Radiology. 2006;241(3):702-9.

56 Yoo JL, Woo OH, Kim YK, Cho KR, Yong HS, Seo BK, et al. Can MR Imaging contribute in characterizing wellcircumscribed breast carcinomas? Radiographics. 2010;30(6):1689-702.

57 Santiago Chinchilla A, Ramos Font C, Custodio Rebollo Aguirre A, Navarro-Pelayo Láinez M, Palacios Gerona H, Llamas Elvira JM. Malignant phyllodes tumor of the breast with lymph node metastasis shown by FDG PET-CT [in Spanish]. Rev Esp Med Nucl. 2010;29(6):314-5.

58 Jacklin RK, Ridgway PF, Ziprin P, Healy V, Hadjiminas D, Darzi A. Optimising preoperative diagnosis in phyllodes tumour of the breast. J Clin Pathol. 2006;59(5):454-9.

59 Lakhani SR, Ellis IO, Schnitt SJ, Tan PH, van de Vijver MJ, editors. World Health Organization Classification of Tumours of the Breast. Lyon, France: IARC; 2012. vol. 4.

60 Noronha Y, Raza A, Hutchins B, Chase D, Garberoglio C, Chu P, et al. CD34, CD117, and Ki-67 expression in phyllodes tumor of the breast: an immunohistochemical study of 33 cases. Int J Surg Pathol. 2011 Apr;19(2):152-8.

61 Tan PH, Jayabaskar T, Yip G, Tan Y, Hilmy M, Selvarajan S, et al. p53 and c-kit (CD117) protein expression as prognostic indicators in breast phyllodes tumors: a tissue microarray study. Mod Pathol. 2005 Dec;18(12):1527-34.

62 Tse GM, Lui PC, Vong JS, Lau KM, Putti TC, Karim R, et al. Increased epidermal growth factor receptor (EGFR) expression in malignant mammary phyllodes tumors. Breast Cancer Res Treat. 2009 Apr;114(3):441-8.

63 Karim RZ, Gerega SK, Yang YH, Spillane A, Carmalt H, Scolyer RA, et al. p16 and pRb immunohistochemical expression increases with increasing tumour grade in mammary phyllodes tumours. Histopathology. 2010 Jun;56(7):868-75.

64 Yasir S, Nassar A, Jimenez RE, Jenkins SM, Hartmann LC, Degnim AC, et al. Cellular fibroepithelial lesions of the breast: a long term follow up study. Ann Diagn Pathol. 2018 Aug;35:85-91.

65 Goto W, Kashiwagi S, Takada K, Asano Y, Morisaki T, Noda S, et al. [A case of a malignant phyllodes tumor that was difficult to distinguish from stromal sarcoma]. Gan To Kagaku Ryoho. 2018 Dec;45(13):2429-31.

66 Burga AM, Tavassoli FA. Periductal stromal tumor: a rare lesion with low-grade sarcomatous behavior. Am J Surg Pathol. 2003 Mar;27(3):343-8.

67 Lu Y, Chen Y, Zhu L, Cartwright P, Song E, Jacobs L, et al. Local recurrence of benign, borderline, and malignant phyllodes tumors of the breast: a systematic review and meta-analysis. Ann Surg Oncol. 2019;26(5):1263-75.

68 Barth RJ Jr, Wells WA, Mitchell SE, Cole BF. A prospective, multi-institutional study of adjuvant radiotherapy after resection of malignant phyllodes tumors. Ann Surg Oncol. 2009;16(8):2288-94.

69 Zeng S, Zhang X, Yang D, Wang X, Ren G. Effects of adjuvant radiotherapy on borderline and malignant phyllodes tumors: a systematic review and meta-analysis. Mol Clin Oncol. 2015;3(3):663-71.

70 Gnerlich JL, Williams RT, Yao K, Jaskowiak N, Kulkarni SA. Utilization of radiotherapy for malignant phyllodes tumors: analysis of the National Cancer Data Base, 1998-2009. Ann Surg Oncol. 2014;21(4):1222-30.

71 Parker SJ, Harries SA. Phyllodes tumours. Postgrad Med J. 2001;77(909):428-35.

72 Belkacémi Y, Bousquet G, Marsiglia H, Ray-Coquard I, Magné N, Malard Y, et al. Phyllodes tumor of the breast. Int J Radiat Oncol Biol Phys. 2008;70(2):492-500.

73 Morales-Vásquez F, Gonzalez-Angulo AM, Broglio K, Lopez-Basave HN, Gallardo D, Hortobagyi GN, et al. Adjuvant chemotherapy with doxorubicin and dacarbazine has no effect in recurrence-free survival of malignant phyllodes tumors of the breast. Breast J. 2007;13(6):551-6.

74 Burton GV, Hart LL, Leight GS Jr, Iglehart JD, McCarty KS Jr, Cox EB. Cystosarcoma phyllodes. Effective therapy with cisplatin and etoposide chemotherapy. Cancer. 1989;63(11):2088-92.

75 Chaney AW, Pollack A, McNeese MD, Zagars GK, Pisters PW, Pollock RE, et al. Primary treatment of cystosarcoma phyllodes of the breast. Cancer. 2000;89(7):1502-11.

76 Borhani-Khomani K, Talman ML, Kroman N, Tvedskov TF. Risk of local recurrence of benign and borderline phyllodes tumors: a Danish population-based retrospective study. Ann Surg Oncol. 2016;23(5):1543-8.

77 Powell CM, Rosen PP. Adipose differentiation in cystosarcoma phyllodes. A study of 14 cases. Am J Surg Pathol. 1994;18(7):720-7.

78 Guerrero MA, Ballard BR, Grau AM. Malignant phyllodes tumor of the breast: review of the literature and case report of stromal overgrowth. Surg Oncol. 2003;12(1):27-37.

79 Tan EY, Tan PH, Hoon TP, Yong WS, Wong HB, Ho GH, et al. Recurrent phyllodes tumours of the breast: pathological features and clinical implications. ANZ J Surg. 2006;76(6):476-80. 